\title{
IS IT POSSIBLE TO TAX INTERNATIONAL TRADE OF ARMS DURING THE CRISIS OF THE TAX STATE?
}

\author{
Feride Berna UYMAZ ${ }^{1}$
}

\begin{abstract}
Global taxes can be used primarily to restrict the production of goods that create negative externalities and/or international organizations which collect revenues of global taxes can use them to solve serious global problems. In this regard, the paper proposes application of semi tax by countries (quasi-taxes in the form of membership) in addition to taxing only military industries. In this case, also the exporting governments would be "taxed" by international agencies such as the International Organization for Migration. The paper also recommends that the tax revenue gathered from both sources should be used for people who have to migrate because of wars. Although an academic contribution can be made on the subject in this way, is it possible to apply this proposal in the real life? The main emphasis point of the paper is to discuss the current state of the capitalist system against theoretical solutions.

In this context, in the first part of the paper the data of the migrations resulting from wars in recent years will be presented and the deaths experienced during the illegal migration process will be pointed out. After discussing the theoretical framework of the loss in tax revenues expressed as the financial crisis of the state and the crisis of tax state, in the second chapter, the proposals for the taxation of arms trade will be presented, analyzed and discussed. In the third part, in addition to the taxation of arms industry, the "taxation" of the arms exporting countries will be discussed as an alternative taxation. Thus, the paper aims to create a mechanism that can contribute to the economic problems of war migrants. Finally the paper draws attentions to the difficulties of implementation of global tax proposals along with the neoliberal policies which inhibits the activations of such proposals.
\end{abstract}

Keywords: Global Taxes, Taxation of the International Arms Trade, Quasi Taxes, Crisis of the Tax State, Forced Migration

JEL Code: H2, H5, H6, H7

\section{Introduction}

In the process of globalization, the mobility of capital in the framework of neoliberal policies erodes the ability of the state to collect tax revenue. In this context, while discussing the crisis of the state, global tax proposals aimed to resolve global problems such as capital movements or climate changes are also being developed. The paper will put forward the applicability of less discussed global tax proposal, such as "taxation of the international arms trade" during the crisis of the tax state.

According to the United Nations Refugee Agency, the number of forcibly displaced people as a result of persecution, conflict, or generalized violence has grown by over $50 \%$ in the last 10 years. Migrants often face many problems, such as racist and exclusionary attitudes towards them. The paper will try to contribute to the solution of this humanitarian drama, at least from the economic perspective.

\footnotetext{
${ }^{1}$ Assoc. Prof. Dr., Istanbul University, Faculty of Economics Department of Public Finance, fbuymaz@istanbul.edu.tr
} 


\section{Migrations Resulting from Wars}

As a result of persecution, conflict, or generalized violence there were 42.7 million forcibly displaced people in 2007, and at the end of 2017 the figure was 68.5 million $42 \%$ of which comprised refugees and 3.1 million asylum-seekers. Today 1 out of every 110 people in the world is displaced (UNHCR, 2018).

The radical increase in the number of forcibly displaced people concentrate between 2013 and 2017, mainly because of the Syrian conflict, other conflicts in the Middle East Region and in sub-Saharan Africa (UNHCR, 2018). More than half (68\%) of the world's refugees in 2017 came from 5 countries: the Syrian Arab Republic (6.3 million), Afghanistan ( 2.6 million) and South Sudan (2.4 million), Myanmar (1.2 million), and Somalia $(986,400)$. The top 5 countries of departure in 2017 by the number of people receiving assistance for resettlement, relocation and humanitarian acceptance were Lebanon, Turkey, Greece, Afghanistan and Italy (UNHCR, 2018).

Among these, the most notable case is a relative surge in irregular migration flows into the region. For example in 2015 over 1 million people arrived in Europe by sea (IOM, 2015). Since 2000 , more than 60,000 migrant deaths (since 2014 , more than 4,000 fatalities annually) have been recorded globally but, it represents only a minimum estimate because the majority of migrant deaths are unrecorded (Migration Data Portal, 2019).

In the following sections, the issue of taxation of international arms trade is discussed with the aim of making a contribution from the economic field to the solution of this humanitarian drama.

\section{The International Arms Trade Tax?}

The International Arms Trade Tax (sometimes called a Weapons Tax or a Gun Tax) has aroused interest in the political arena. Its supporters include a number of politicians and influential theoreticians in areas related to developmental problems (Brzoska, 2004a: 150). However, this tax appears to be not only one of the least well developed proposals but also one of the least likely to be implemented ones (Bird, 2014: 25).

Many interrelated objectives can be seen in these proposals on arms trade tax. The main target is to increase the cost of arms trade by imposing taxation which will then reduce the amount of arms transactions and expenditure on imports of arms and increase the revenue of international funds that can, in return, be used to compensate those who have suffered from armed conflicts (Brzoska, 2004a: 151; Brzoska, 2017a: 1; Brzoska. 2017b).

The five biggest exporters of arms in 2012-2016 were the United States, Russia, China, France and Germany and, the five biggest importers were India, Saudi Arabia, the United Arab Emirates (UAE), China and Algeria (Fleurant, Wezeman, Wezeman \& Tian, 2017: 1). According to SIPRI, the financial volume of the arms trade was estimated at about 374.8 billion in 2016, so even a relatively low tax rate imposed, for instance $10 \%$, could cover all the costs of "United Nations Peacekeeping Fund" which was \$7,8 billion for the fiscal year of 2016-2017 (Brzoska, 2017b).

However, besides important methodological problems, there are objections to the taxation of arms. It is thought that this tax will be shifted to the underdeveloped countries where wars take place and that tax cannot be processed due to problems of accountability of these low-income countries and it is also considered that application of such a tax will rationalize the high amount of arms trade (Brzoska, 2004a: 152 \& Brzoska, 2017a: 1). 


\section{An Alternative: A Quasi-Tax?}

Nowadays, the analysis of the relations of the states with the arms industry shows the existence of a complementary structure between them. In particular, the military-industrial complex affects the state's policies for the creation the necessary demand for military equipment in order to guarantee profit for the arms industry (Mann, 1987: 44 and Shaw, 2002). It should also be noted that the military industrial complex forms reciprocal links also with other producers for the production of by-product regarding their industry. Furthermore, monopoly capital of the military-industrial complex is able to direct the state's economic policies (Kidron, 1967). The exportations of militaryindustrial complex are supported through direct subsidies, marketing subsidies, operational support and initial research and development allowance (Brzoska, 2004a: 163-165).

This report also draws attention to preferential financial support in the form of market-based financing and contingent assistance provided by export credit agencies to arms industry, directly and indirectly. Financial support for arms trade rejected by international financial institutions is provided by export credit agencies which undertake potential losses for arms exporters. Export credit-backed loans that are provided to developing countries create the most important source of debt in these countries and raise the level of their contingent liabilities. In addition, the scope of conditional aid is also high in the area of military assistance, covering the cost of imported weapons or military services (Uymaz, 2018: 64-68).

In this context, the intricate relationship between the arms industry and the governments shows that the exporting state should also be included in the analysis in order to limit the negative effects of the arms industry.

An interesting alternative can be a quasi-tax in the form of membership assessments of international organizations in which case the arms exporting government would be "taxed" by international organizations. (Brzoska, 2017b). As the quasi-tax doesn't have any effect on the demand for arms trade, it would also mean that this practice would cause greater revenues than arms trade tax (Brzoska, 2017a: 3).

In this context, this paper recommends that arms exporting companies should be taxed and in addition the arms exporting countries should also pay a membership fee in the form of quasi-tax. For example, the company $X$, which exports arms to Syria, must pay international arms trade tax, and also the country of the company $X$ must pay a fee to an international fund as a cost of supporting arms trade. Income from both channels can be transferred to a fund managed by an international organization, like the International Migration Administration, and used to economically compensate forcibly displaced people around the world.

\section{Conclusion}

One objective of this paper is to theorize the methods for the war industry to compensate the consequences of the use of its output, in other words, to be responsible for the economic recovery of the victims of the war. In the framework of the neoclassical theory, the paper aims to internalize the negative externalities of the weapons industry.

To say that there is a direct relationship between the development of the war industry and the increasing number of wars is to ignore the other causes of the wars. Nevertheless, "the supply mechanism of the war industry creating its own demand" can be followed by the support of 
the state, providing purchase guarantee. In this context this paper offers ways to decrease arms trade and generate some revenue by the taxation of the international arms trader and arms exporting countries. In relation with the mainstream economics, an offer of taxing both arms industries and the arms exporting governments and collecting the revenue in an international fund to use it in the compensation of forcibly displaced people can be considered to be an academic contribution. However, it is quite possible that this proposal will remain only as an offer without being realized like other global tax proposals made in the history. Reasons for this have to be interpreted by the analysis of the capitalist system and the economic structure that have caused the crisis of today's tax state.

\section{References}

Bird, R.M. (2014). Global taxes and international taxation: mirage and reality. International Center for Public Policy Working Paper Series. Paper 31. https://scholarworks.gsu.edu/ cgi/viewcontent.cgi?article=1016\&context=icepp (10 02 2018).

Brzoska, M. (2004a). Taxation of the global arms trade? An overview of the issues. KYKLOS. Vol. 57.Fasc., pp.149-172. http://carecon.org.uk/Chula/2004\%20Brzoska\%20Kyklos.pdf (02 02 2018).

Brzoska, M. (2017a). Core issues of an arms trade tax. STOCKHOLM FORUM on Peace and Development. Participant Reflection, pp.1-5. https://www.sipri.org/sites/default/ files/2017-09/participant_reflection_arms_trade_tax.pdf (14 02 2018).

Brzoska, M. (2017 b). A tax on the arms trade to fund peacebuilding?. TMS PEACE JOURNALISM, MILITARISM, IN FOCUS, 6 Nov 2017.https://www.transcend.org/tms/2017/11/ a-tax-on-the-arms-trade-to-fund-peacebuilding/ (12 03 2018).

Fleurant, A., Wezeman, P.T., Wezeman, S.T. \& Tian, N. (2017). "Trends in International Arms Transfers-2016". SIPRI. (19.03.2019).

IOM. (2015). IOM Releases Global Migration Trends 2015 Factsheet https://www.iom.int/news/ iom-releases-global-migration-trends-2015-factsheet (22 03.2019).

Kidron, M. (1967). “A Permanent Arms Economy", International Socialism. (1st series), No.28, Illkbahar, s.8-12.

Mann, M. (1987). "The Roots and Contradictions of Modern Mlitarism", New Left Review , No: 162, Mart-Nisan, s.35-50.

Migration Data Portal. (2019). https://migrationdataportal.org/themes/migrant-deaths-anddisappearances. (26.02.2019).

Shaw, M. (2002). Dialectics of War-An Essay in the Social Theory of total War and Peace, Pluto Press, UK, 1988, http://www.theglobalsite.ac.uk/press/204shaw.htm, (14. 05.2009).

UNHCR (The UN High Commissioner for Refugees). (2018). Global Trends FORCED DISPLACEMENT IN 2017. https://www.unhcr.org/5b27be547.pdf. (25.02.2019).

Uymaz, B. (2018). "Taxation of the Arms Trade versus Subsidization of the Arms Trade", in: Current Debates in Public Finance Public Administration, MUTLU AKAR, S., ŞENBEL E., Eds., Ijopec Publications, Londra, pp.57-71. 